\title{
Essential oil from Piperaceae as a potential for biopesticide agents: a review
}

\author{
${ }^{1}$ Abdullah, N.A., ${ }^{1,2}$ Zain, W.Z.W.M., ${ }^{1}$ Hamid, N.A. and ${ }^{1}$ Ramli, N.W. \\ ${ }^{I}$ Faculty of Plantation and Agrotechnology, Universiti Teknologi MARA (UiTM), Cawangan Melaka, \\ Kampus Jasin, Merlimau, Melaka \\ ${ }^{2}$ Pejabat Program Pra Pendidikan Tinggi UiTM, Universiti Teknologi MARA (UiTM) Shah Alam, 40450, \\ Shah Alam, Selangor
}

\begin{abstract}
Article history:
Received: 22 July 2020

Received in revised form: 5

November 2020

Accepted: 26 September 2020

Available Online: 20

December 2020
\end{abstract}

Keywords:

Chemical component,

Essential oil,

Piperaceae,

Antimicrobial,

Insecticidal

DOI:

https://doi.org/10.26656/fr.2017.4(S5).007

\begin{abstract}
This review is aimed to present information on the properties of Piperaceae which can be potentially used as a biopesticide. The chemical compounds involved in were different as each species consist of different amount of secondary metabolites which then leads to different properties. In recent years, several reports have been published regarding the composition and the biological activities of the essential oils of Piper species. These studies have highlighted the existence of marked chemical differences among oils extracted from different species or varieties. Analysis of volatile constituents from Piperaceae species has revealed the presence of monoterpenes, sesquiterpenes and arylpropanoids that have shown interesting biological properties including cytotoxic, fungistatic, insecticide, molluscicidal, antioxidant and antimicrobial activities. Essential oils are natural complex secondary metabolites characterized by strong odour, volatility and have generally lower density than water. Due to their volatility, essential oils are environmentally non-persistent. On top of that, essential oils are 'generally recognized as safe' by the United States Food and Drug Administration (FDA). Since technology has become more advanced, people started to replace synthetic pesticide with bio-pesticide. The demand for EO has increased as it has biological properties that can be used to replace synthetic pesticide.
\end{abstract}

\section{Introduction}

Piperaceae or piper is famous and widely known around the world. Pepper was originated from Ghat Barat and Malabar in western India. It was brought to Malaya (Malaysia) through the port of Melaka by the Portuguese centuries ago. It then became the main product traded in the port of the states of Johor and Singapore. Later on, the cultivation for pepper crop expanded to Sarawak and it became Sarawak's main export product. This crop comes from a large family in flowering plants. The order Piperales represented the largest basal angiosperm that has been distributed worldwide. This order consists of three species, Piper, Peperomica, and Aristolochia. Piperaceae contains about 3,600 species roughly. These species are the ones that were currently accepted in the 13 genera. The pepper's vast majority can be found within the two main genera, Piper and Peperomia. The most known species is Piper nigrum or black pepper which produced peppercorns that are used as spices all over the world. In Malaysia, there were a few well-known species that are usually cultivated in places such as Kuching, Semenggok Perak, Semenggok Emas and many more. There were also many well-known species in other producing countries such as Belantung (Indonesia), Karimunda (India), Djambi (Indonesia) and Bangka (Indonesia) (Mah, 2017). Thus, the aim for this review was to reveal the properties of the Piperaceae species to be used as potential biopesticide along with its chemical compounds which have been proven to be responsible for each of the properties stated.

\section{Ethnomedicinal uses of Piperaceae}

Out of all the various species, Piper nigrum L. or known as black pepper has a prominent position and this species was acknowledged as the "King of Spices". It has many functional uses in traditional food formulations, perfumery, kitchen, and even beauty care. Besides that, pepper was also used for its medicinal properties. Black pepper has been used in the Asian folk 
medicine and the Indian Ayurvedic System of medicine folklore medicine of Latin America since many years ago (Tu et al., 2015). Pepper was also reported that it has been used in folk medicine to treat several ailments (Wan Salleh et al., 2014). Table 1 shows some of the species along with their traditional uses. Most of the species contain antioxidant activities which can be used to fight against fever, asthma, coughs, diarrhoea and many more. Based on previous reports, there were only a few studies on the chemical compounds of Piperaceae which can be used as bio-pesticides.

Table 1. List of pepper and their traditional uses (Wan Salleh et al., 2014).

\begin{tabular}{ll}
\hline \multicolumn{1}{c}{ Species } & \multicolumn{1}{c}{ Traditional uses } \\
\hline Piper caninum & $\begin{array}{l}\text { Chewing, hoarseness, flavour, throat } \\
\text { ache, antiseptic }\end{array}$ \\
\hline Piper lanatum & $\begin{array}{l}\text { Malaria, toothache, rheumatism, } \\
\text { deworming, fever, influenza, ulcer }\end{array}$ \\
\hline Piper abbreviatum & $\begin{array}{l}\text { Splenomegaly, stimulant, carminative, } \\
\text { coughs \& colds, flatulence }\end{array}$ \\
\hline Piper aborescens & $\begin{array}{l}\text { Rheumatism, antiplatelet aggregation, } \\
\text { cytotoxic }\end{array}$ \\
\hline Piper porphyrophyllum & $\begin{array}{l}\text { Leprosy, abdominal pain, skin disease, } \\
\text { postpartum treatment, bone pain }\end{array}$ \\
\hline Piper erecticaule & No reports \\
\hline Piper ribesioides & $\begin{array}{l}\text { Asthma, diarrhoea, abdominal pain, } \\
\text { flavour, alleviate chest congestion, } \\
\text { treat urticaria }\end{array}$ \\
\hline Piper miniatum & $\begin{array}{l}\text { Spice, food flavour, food natural } \\
\text { preservative, antibacterial }\end{array}$ \\
\hline Piper stylosum & $\begin{array}{l}\text { Vegetables, seasoning, poultice/ } \\
\text { decoction, confinement }\end{array}$ \\
\hline Piper majusculum & No reports \\
\hline
\end{tabular}

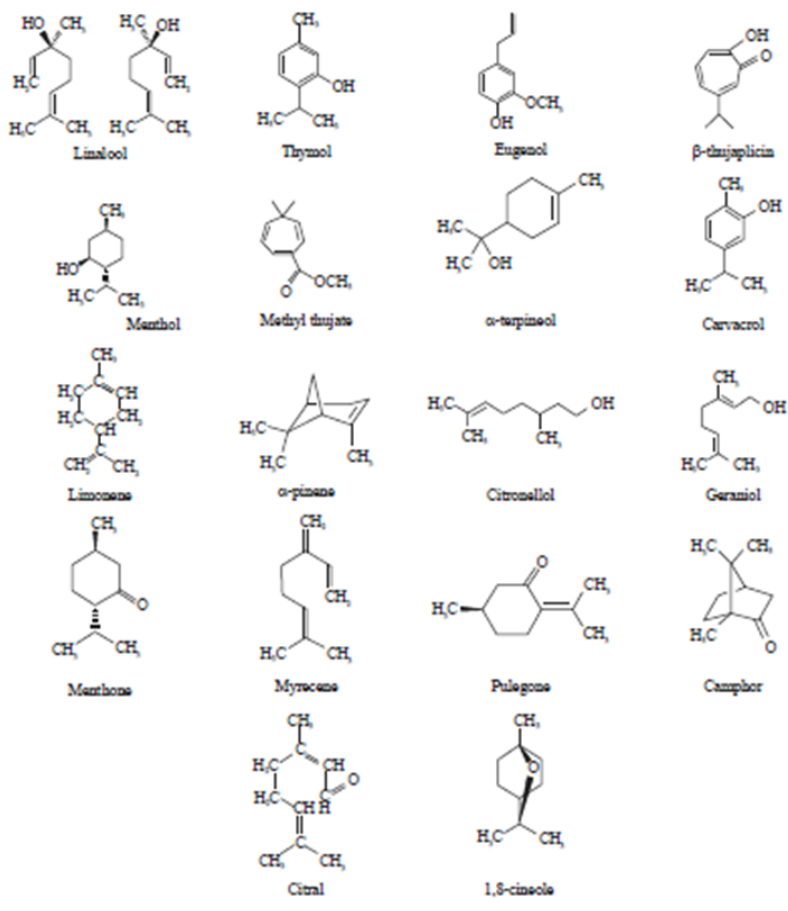

Figure 1. Chemical structures found in essential oil (Mossa, 2016).

\section{Bio-pesticide}

Bio-pesticide is an alternative to synthetic pesticides. It produces the same effects the chemical pesticides but it is made from naturally occurring formulations to control pests through non-toxic mechanisms and in an eco-friendlier manner (Kumar and Singh, 2015). Biopesticide was derived from plants, animals, bacteria as well as minerals that were used for pest control (Kachhawa, 2017; Lengai and Muthomi, 2018). It is included in the strategy used in Integrated Pest Management or IPM to control pest and disease and it has been proven to be successfully reduced the usage of chemical pesticides in the field (Krishnen et al., 2016). Figure 1 shows some of the chemical structures found in an EO that has insecticidal activities.

\subsection{Essential oil}

Essential oils (EOs) can be classified into volatile, semi-volatile and non-volatile compounds depending on their nature (Eslahi et al., 2017). EOs are antimicrobials that occurs naturally where it can be found in many plants and it has shown to be effective in many applications by lowering the growth and survival capabilities of microorganisms (Calo et al., 2015). It plays many important in a plant's defence system against herbivores and pathogens. EOs' synthesis and accumulation were associated with secretory structures such as oil cells, secretory ducts or cavities, glandular trichomes, resin ducts (Pavela and Benelli, 2016; Morsy, 2017).

Generally, EOs have been known for their biological properties such as insecticidal, ovicidal, nematicidal, bactericidal and fungicidal effects against pests and pathogens that were very important in the agricultural yield including having positive effects on inflammatory processes, cardiovascular diseases, oxidative diseases, analgesic, anti-inflammatory activities (Isman et al., 2011; Andrés et al., 2012; González-Coloma et al., 2013; Pacheco et al., 2016; Santana et al., 2016; Andres et al., 2017; Eslahi et al., 2017). Essential oils can be categorized into terpenoids and phenylpropanoids. Terpenoids are the major constituents for EOs. It consists of monoterpenes and sesquiterpenes of low molecular weight while phenylpropanoids have a lesser extent (Regnault-Roger et al., 2012; Roman and Benelli, 2016).

Essential oils are being used as bio-pesticide because of its various biological activities against different insects, pest and pathogen. Table 2 below shows some of the species in the family of Piperaceae, type of insect or pathogen tested, chemical component extracted, properties identified, and the results observed. As we can see from the table, Gram-positive bacteria 
were effective when it was against essential oils. In order for the essential oils to be effective towards the microorganisms tested, the concentration must be taken into consideration (Premachandra et al., 2014). According to Premachandra (2014), the findings on leaf extract from Piper betle L., has a high potency of nemato -toxic activity which can be directly related to the concentration of the leaf extract. In simple language, the higher the dose, the better the efficacy of the extract. The results demonstrated that the essential oils and plant parts showed significant bioactivity properties which can be used against various diseases as preventive agents. Based on previous studies, it is concluded that single compounds such as 1,8-cineole, myrcene, $\alpha$-pinene, $\beta$ pinene and camphor are commonly found in essential oils associated with biological properties such as antifungal activity. However, the compound mentioned are absent in Piper abbreviatum, Piper erecticaule and Piper lanatum which proves that the antifungal activity does not depend solely on the compounds present but also the synergistic, antagonistic or additive effects of the compounds itself (Salleh et al., 2011; Salleh et al., 2014).

A high content of monoterpene hydrocarbons may be the reason why the essential oils lack activity against the microbial strains tested. Moreover, study shows essential oils that have a high content of oxygenated monoterpenes displayed stronger antifungal properties (Salleh et al., 2012). The essential oils are weak when it is tested for antifungal property due to the small number of oxygenated monoterpenes.

The phenol, apiol and dillapiole compounds show their potential as insecticidal against several insects and also major insect pest in food crop such as termites. This is a good and important finding to maximise the uses of essential oil extracted from Piperaceae. The essential oil extracted from the plant is very limited. However, the Piperaceae essential oil shows high potential in controlling pests in a food crop with low amount which is good to be commercialised worldwide as a biopesticide.

\section{Conclusion and Recommendation}

The usage of chemical pesticides has caused many adverse toxic effects. One of the major concerns nowadays is the pollution and contamination of soil because of the excessive use of chemicals which can cause environmental pollution at both manufacturing and application sites. In addition to that, it causes many health and environmental problems, affected many factors such as survival range of life cycle stages, reduce reproductive capacity, changes host suitability for parasitizing and predation, reduces the emergence of parasitoids and also causes mortality. The search for alternatives to chemical pesticides has become a priority. Sustainable method to overcome this problem has become a great challenge, especially to smallholders. Thus, bio-pesticides have been invented with the help of technologies. Bio-pesticides have become one of the alternatives chosen although it does not reach the desired level of use yet. This alternative had received many positive interests to replace the synthetic pesticides which are very suitable for integrated pest management (IPM) and organic farming. The potential group of biopesticides were represented by EO which was known to possess many biological activities including controlling pests and repellent properties. During this globalisation era, the concept of returning to "roots" is starting to become more famous. Scientific research also proved that plants such as Piperaceae can be used as biopesticide. Based on Table 2, mosquitoes can be controlled by using five species of Piper which Piper betle L., Piper dilatatum, Piper aff. Hispidum, and Piper sanctifelicis due to the presence of phenol, chavicol, apiol, trans-caryophyllene, p-cymene and limonene. Besides, Escherichia coli and Staphylococcus aureus can be controlled by using EO from Piper nigrum which contains $\beta$-caryophyllene and limonene, and piperine respectively while Xanthomonas oryzae pv. Oryzae and Pseudomonas fuscovaginae can be controlled using secondary metabolite presence in Piper sarmentosum such as 4H-pyran-4-one,2,3-dihydro-3,5-dihydroxy- 6methyl- (DDMP);octanamide, N,N-dimethyl;3-(4methoxyphenyl) propionic acid. Moreover, brown planthopper and leaf folder pathogen can be controlled using Piper divaricatum which contains eugenol and methyl-eugenol. Piper guineense contains sesquiterpene $\beta$-sesquiphellandrene and linalool which possessed many biological activities. Being exposed to many pest and diseases ensures plants produce resistance mechanisms such as secondary metabolites to protect themselves. Piper aduncum L. exhibit potential insecticidal activity against caterpillar soybean looper (Chrysodeixis includes Walker) through ingestion. Piper nigrum was the most researched species because Piper nigrum is the most abundant species in this genus. Thus, more research should be done on the chemical compounds of the other species of Piper in order to carry out comparative studies with emphasis on the mechanisms, to publish and to organize a workshop where new findings are presented and control methods are critically analysed in relation to the feedback from farmers. 


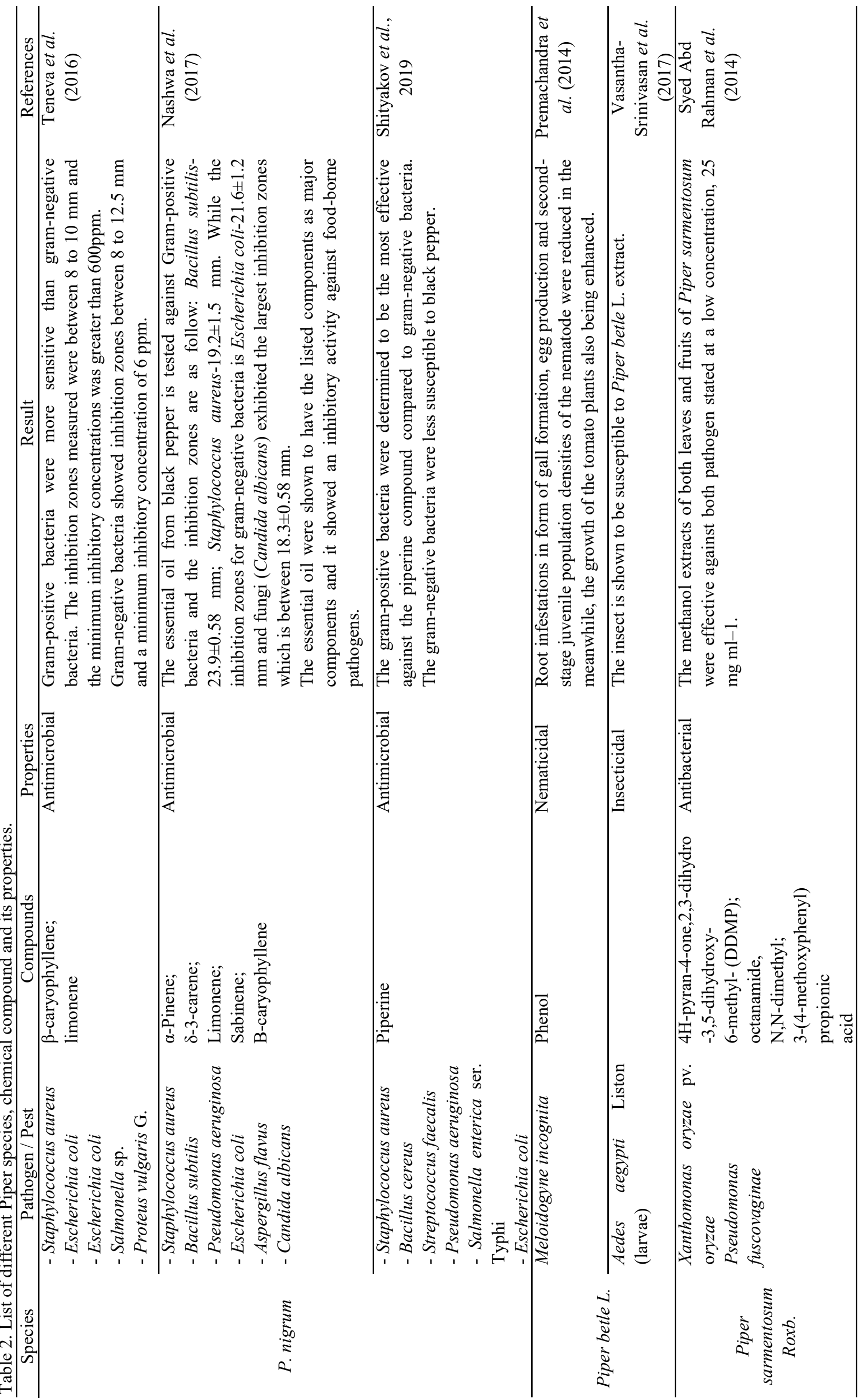


Abdullah et al. / Food Research 4 (Suppl. 5) (2020) 1 - 10

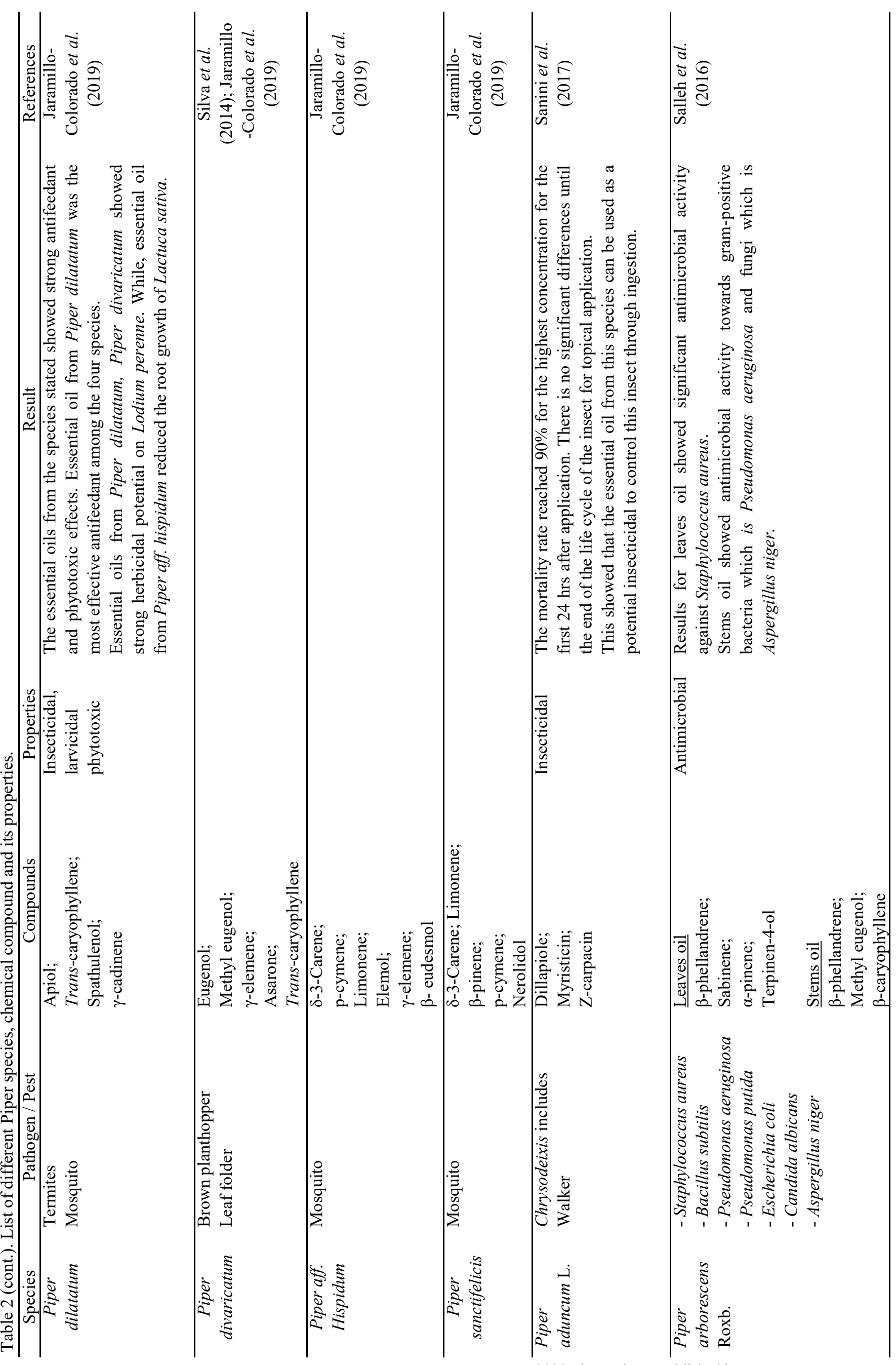




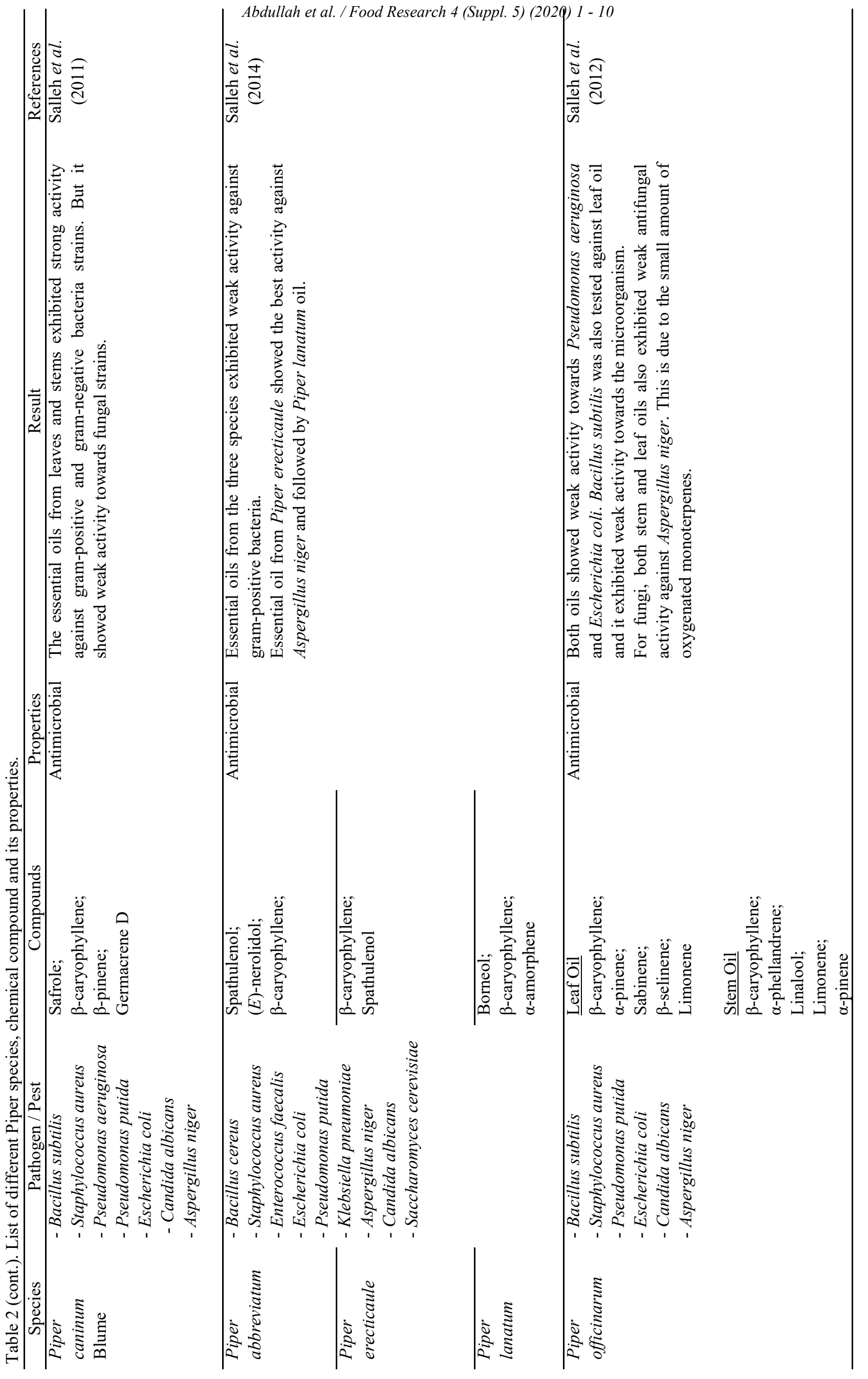




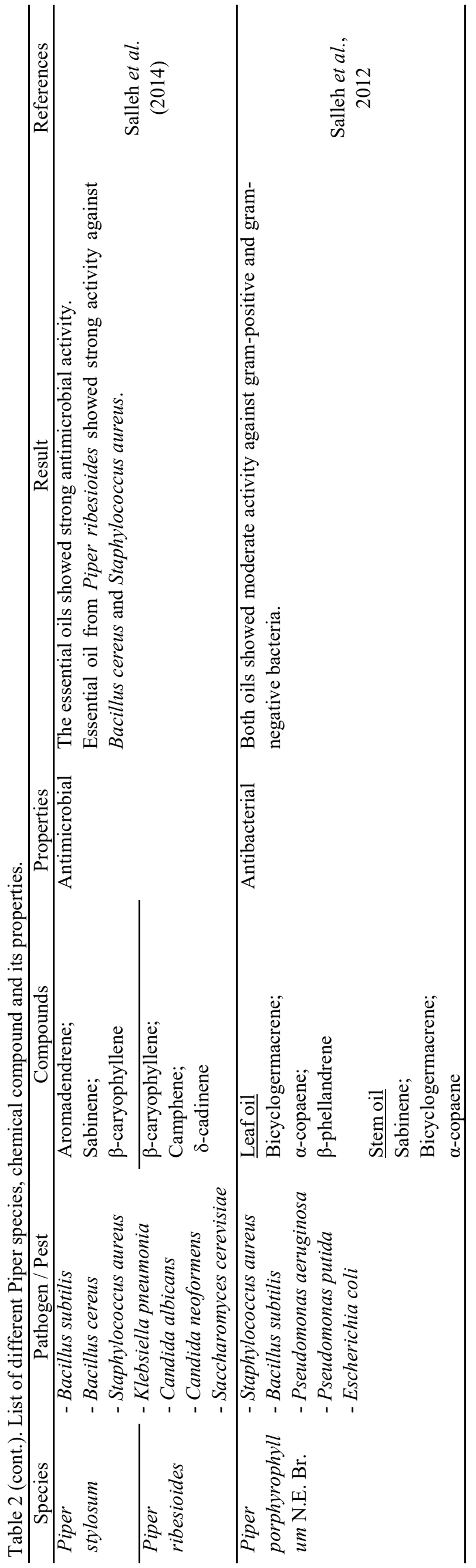




\section{References}

Abdallah, Q.M. and Abdalla, W.E. (2018). Black pepper fruit (Piper nigrum L.) as antibacterial agent: A mini -review. Journal of Bacteriology and Mycology: Open Access, 6(2), 141-145. https:// doi.org/10.15406/jbmoa.2018.06.00192

Andres, M.F., Rossa, G.E., Cassel, E., Vargas, R.M., Santana, O., Diaz, C.E. and Gonzalez-Coloma, A. (2017). Biocidal effects of Piper hispidinervu (Piperaceae) essential oil and synergism among its main components. Food and Chemical Toxicology, 109(2), 1086-1092. https://doi.org/10.1016/ j.fct.2017.04.017

Bagheri, H., Abdul Manap, M. and Solati, Z. (2014). Antioxidant activity of Piper nigrum L. essential oil extracted by supercritical $\mathrm{CO} 2$ extraction and hydrodistillation. Talanta, 12, 220-228. https:// doi.org/10.1016/j.talanta.2014.01.007

Calo, J.R., Crandall, P.G., O'Bryan, C.A. and Ricke, S.C. (2015). Essential oils as antimicrobials in food systems - A review. Food Control, 54, 111-119. https://doi.org/10.1016/j.foodcont.2014.12.040

Camorro, E.R., Zambon, S.N., Morales, W.G., Sequeira, A.F. and Velasco, G.A. (2012). Study of the chemical composition of essential oils by gas chromatography. In Salih, B. (Ed). Gas Chromatography in Plant Science, Wine Technology and Some Specific Applications, p. 307-324. Rijeka, Croatia: Intech.

Damalas, C.A. and Koutroubas, S.D. (2018). Current Status and Recent Developments in Biopesticide Use. Agriculture, 8(1), 13. https://doi.org/10.3390/ agriculture 8010013

Dhakal, R. and Singh, D.N. (2019). Biopesticides: A Key to Sustainable Agriculture. International Journal of Pure and Applied Bioscience, 7(3), 391-396. https:// doi.org/10.18782/2320-7051.7034

Eslahi, H., Fahimi, N. and Sardarian, A.R. (2017). Chemical Composition of Essential Oils. In Essential Oils in Food Processing: Chemistry, Safety and Applications, 119-171. https:// doi.org/10.1002/9781119149392.ch4

Jaramillo-Colorado, B.E., Pino-Benitez, N. and Gonzalez -Coloma, A. (2019). Volatile composition and biocidal (antifeedant and phytotoxic) activity of the essential oils of four Piperaceae species from ChocoColombia. Industrial Crop and Products, 138(4), 111463. j.indcrop.2019.06.026

Kachhawa, D. (2017). Microorganisms as a biopesticides. Journal of Entomology and Zoology Studies, 5(3), 468-473.
Keong, M.S. (2017). Bright future for Sarawak pepper. Retrieved 25 September, 2019, from The Star Online website: https://www.thestar.com.my/news/ nation/2017/10/25/malaysia-aims-to-be-worlds-topsupplier-of-the-premium-king-of-spices

Krishnen, G., Mohd. Noor, M.R., Jack, A. and Haron, S. (2016). Research, Development and Commercialisation of Agriculturally Important Microorganisms in Malaysia. In Singh, H., Sarma, B. and Keswani, C. (Eds). Agriculturally Important Microorganisms, p. 149-166. Singapore: Springer. https://doi.org/10.1007/978-981-10-2576-1_9

Kumar, S. and Singh, A. (2015). Biopesticides: Present Status and the Future Prospects. Journal of Fertilizers and Pesticides, 6(2), 1000e129. https:// doi.org/10.4172/2471-2728.1000e129

Kumari, K.A., Kumar, K.N. and Rao, C.N. (2014). Adverse Effects of Chemical Fertilizers and Pesticides an Human Health and Environment. Journal of Chemical and Pharmaceutical Sciences, $3,150-151$.

Lengai, G.M. and Muthomi, J.W. (2018). Biopesticides and Their Role in Sustainable Agricultural Production. Journal of Biosciences and Medicines, 6 (6), 7-41. https://doi.org/10.4236/jbm.2018.66002

Liang, Z.L. and Guo, X.J. (2015). Comparative Study on Antioxidant Activity of Essential Oil from White and Black Pepper. European Journal of Food Science and Technology, 3(3), 10-16.

Maksymiv, I. (2015). Pesticides: benefits and hazards. Journal of Vasyl Stefanyk Precarpathian National University, 2(1), 70-76. https://doi.org/10.15330/ jpnu.2.1.70-76

Mehrotra, S., Kumar, S., Zahid, M. and Garg, M. (2017). Biopesticides. In Singh, R.L. (Ed). p. 273-292. Management and Remediation of Problem Soils, Solid Waste and Soil Pollution. Singapore: Springer. https://doi.org/10.1007/978-981-10-1866-4_8

Mgbeahuruike, E., Trjonen, T., Vuorela, H. and Holm, Y. (2017). Bioactive compounds from medicinal plants: focus on Piper species. South African Journal of Botany, 12, 54-69. https://doi.org/10.1016/ j.sajb.2017.05.007

Morsy, N.F. (2017). Chemical Structure, Quality Indices and Bioactivity of Essential Oil Constituents. In Aromatic and Medicinal Plants. IntechOpen. https:// doi.org/10.5772/66231

Mossa, A.-T.H. (2016). Green pesticides: Essential Oils as Biopesticides in Insect-Pest Management. Journal of Environmental Science and Technology, 9(5), 354 -378. https://doi.org/10.3923/jest.2016.354.378

Myszka, K., Schmidt, M.T., Majcher, M., Juzwa, W. and 
Czaczyk, K. (2017). ß-Caryophyllene-Rich Pepper Essential Oils Suppress Spoilage Activity of Pseudomonas Fluorescens KM06 in Fresh-Cut Lettuce. Food Science and Technology, 83, 118-126. https://doi.org/10.1016/j.lwt.2017.05.012

Nashwa, F.M. and Abd El-Salam, E.A. (2017). Antimicrobial and Antiproliferative Activities of Black Pepper (Piper nigrum L.) Essential Oil and Oleoresin. Journal of Essential Oil Bearing Plants, 20(3), 779-790. https:// doi.org/10.1080/0972060X.2017.1341342

Ndakidemi, B., Mtei, K. and Ndakidemi, P.A. (2016). Impacts of Synthetic and Botanical Pesticides on Beneficial Insects. Agricultural Science, 7(6), 364372. https://doi.org/10.4236/as.2016.76038

Ngo, Q.M., Cao, T.Q., Hoang, L.S., Ha, M.T., Woo, M.H. and Min, B.S. (2018). Cytotoxic Activity of Alkaloids from the Fruits of Piper nigrum. Natural Product Communications, 13(11), 1467-1469. https://doi.org/10.1177/1934578X1801301114

Oyemitan, I.A., Olayera, O.A., Alab, A., Abbas, L.A., Elusiyan, C.A., Oyedeji, A.O. and Akanmu, M.A. (2015). Psychoneuropharmacological Activities and Chemical Composition of Essential Oil of Fresh Fruits of Piper guineense (Piperaceae) in Mice. Journal of Ethnopharmacology, 166, 240-249. https://doi.org/10.1016/j.jep.2015.03.004

Pavela, R. and Benelli, G. (2016). Essential Oils as Ecofriendly Biopesticides? Challenges and Constraints. Trends in Plant Science, 21(12), 10001007. https://doi.org/10.1016/j.tplants.2016.10.005

Premachandra, W.D., Mampitiyarachchi, H. and Ebssa, L. (2014). Nemato-toxic potential of Betel (Piper betle L.) (Piperaceae) leaf. Crop protection, 65, 1-5. https://doi.org/10.1016/j.cropro.2014.06.004

Regnault-Roger, C., Vincent, C. and Arnason, J.T. (2012). Essential Oils in Insect Control: Low-Risk Products in a High-Stakes World. Annual Review of Entomology, 57, 405-24. https://doi.org/10.1146/ annurev-ento-120710-100554

Salleh, W., Ahmad, F. and Khong, H.Y. (2014). Chemical composition of Piper stylosum Miq. and Piper ribesioides Wall. Essential Oils, and their Antioxidant, Antimicrobial and Tyrosinase Inhibition Activities. Boletín Latinoamericano y del Caribe de, 13(5), 488-497.

Salleh, W., Ahmad, F. and Khong, H.Y. (2014). Chemical Compositions and Antimicrobial Activity of the Essential Oils of Piper abbreviatum, Piper erecticaule and Piper lanatum (Piperaceae). Natural Product Communications, 9(12), 1795-1798. https:// doi.org/10.1177/1934578X1400901235
Salleh, W., Ahmad, F. and Khong, H.Y. (2016). Essential Oil Compositions and Antimicrobial Activity of Piper arborescens Roxb. Marmara Pharmaceutical Journal, 20(2), 111-115. https:// doi.org/10.12991/mpj.20162071871

Salleh, W., Ahmad, F., Khong, H.Y. and Sirat, H.M. (2011). Chemical Compositions, Antioxidant and Antimicrobial Activities of Essential Oils of Piper caninum Blume. International Journal of Molecular Sciences, 12(11), 7720-7731. https:// doi.org/10.3390/ijms 12117720

Salleh, W., Ahmad, F., Khong, H.Y. and Sirat, H.M. (2012). Chemical Compositions, Antioxidant and Antimicrobial Activity of the Essential Oils of Piper officinarum (Piperaceae). Natural Product Communications, 7(12), 1659-1662. https:// doi.org/10.1177/1934578X1200701229

Salleh, W., Ahmad, F., Sirat, H.M. and Khong, H.Y. (2012). Chemical Compositions and Antibacterial Activity of the Leaf and Stem Oils of Piper porphyrophyllum (Lindl.) N.E. Br. EXCLI Journal, 1, 399-406.

Sanini, C., Massarolli, A., Krinski, D. and Butnariu, A.R. (2017). Essential Oil of Spiked Pepper, Piper aduncum L. (Piperaceae), for the Control of Caterpillar Soybean Looper, Chrysodeixis includens Walker (Lepidoptera: Noctuidae). Brazilian Journal of Botany, 40(2), 399-404. https://doi.org/10.1007/ s40415-017-0363-6

Santana, A.I., Vila, R., Canigueral, S. and Gupta, M.P. (2016). Chemical Composition and Biological Activity of Essential Oils from Different Species of Piper from Panama. Planta Medica, 82(11), 986991. https://doi.org/10.1055/s-0042-108060

Shityakov, S., Bigdelian, E., Hussein, A.A., Hussain, M.B., Tripathi, Y.C., Khan, M.U. and Shariati, M.A. (2019). Phtochemical and Pharmacological Attributes of Piperine: A Bioactive Ingredient of Black Pepper. European Journal of Medicinal Chemistry, 176, 149-161. https://doi.org/10.1016/ j.ejmech.2019.04.002

Silva, J.K.R.D., Silva, J.R.A, Nascimento, S.B., Da Luz, S.F.M., Meireles, E.N., Alves, C.N., Ramos, A.R. and Maia, J.G.S. (2014). Antifungal Activity and Computational Study of Constituents from Piper divaricatum Essential Oil against Fusarium Infection in Black Pepper. Molecules, 19(11), 17926-17942. https://doi.org/10.3390/molecules 191117926

Syed Ab Rahman, S.F., Sijam, K. and Omar, D. (2014). Chemical Composition of Piper sarmentosum Extracts and Antibacterial Activity against the Plant Pathogenic Bacteria Pseudomonas Fuscovaginae and Xanthomonas oryzae pv. oryzae. Journal of 
Plant Diseases and Protection, 121(6), 237-242. https://doi.org/10.1007/BF03356518

Teneva, D., Denkova, Z., Goranov, B., Denkova, R., Kostov, G., Atanasova, T. and Merdzhanov, P. (2016). Chemical Composition and Antimicrobial Activity of Essential Oils from Black Pepper, Cumin, Coriander and Cardamom against some Pathogenic Microorganisms. Food Technology, XX (2), 39-52. https://doi.org/10.1515/aucft-2016-0014

Trivedi, M.N., Khemani, A., Vachhani, U.D., Shah, C.P. and Santani, D.D. (2011). Pharmacognostic, Phtyochemical Analysis and Antimicrobial Activity of two Piper Species. International Journal of Comprehensive Pharmacy, 2(7), 1-4.

University of Hawaii Botany Department. (2006). Retrieved from Vascular Plant Family access page: http://www.botany.hawaii.edu/faculty/carr/ pfamilies.htm

Untachai, J., Dodgson, W., Srifa, A. and Dodgson, J.L. (2018). In-Vitro Antibacterial Activities of Selected Traditional Plants. Journal of Pure and Applied Microbiology, 12, 265-277. https://doi.org/10.22207/ JPAM.12.1.31

Vasantha-Srinivasan, P., Senthil-Nathan, S., Ponsakar, A., Thanigaivel, A., Edwin, E.S., Selin-Rani, S., Chellappandian, M., Pradeepa, V., Lija-Escaline, J., Kalaivani, K., Hunter, W.B., Duraipandiyan, V. and Al-Dhabi, N.A. (2017). Comparative Analysis of Mosquito (Diptera: Culicidae: Aedes aegypti Liston) Responses to the Insecticide Temephos and Plant Derived Essential Oil derived from Piper betle L. Ecotoxicology and Environmental Safety, 139, 439446. https://doi.org/10.1016/j.ecoenv.2017.01.026

Vasantha-Srinivasan, P., Senthil-Nathan, S., Ponsankarl, A., Thanigaivel, A., Chellappandial, M., Edwin, E.S.,Selin-Rani, S., Kalaivani, K., Hunter, W.B., Duraipandiyan, V., Al-Dhabi, N.A. (2017). Acute Toxicity of Chemical Pesticides and Plant-Derived Essential Oil on the Behavior and Development of Earthworms, Eudrilus eugeniae (Kinberg) and Eisenia fetida (Savigny). Environmental Science and Pollution Research International, 25(11), 1037110382. https://doi.org/10.1007/s11356-017-9236-6

Voris, D.G.d.R.V., Dias, L.D.S., Lima, J.A., Lima, K.D.S.C., Lima,J.B.P. and Lima, A.L.D.S. (2018). Evaluation of Larvicidal, Adulticidal, and Anticholinesterase Activities of Essential Oils of Illicium verum Hook. f., Pimenta dioica (L.) Merr., and Myristica fragrans Houtt. against Zika Virus Vectors. Environmental Science and Pollution Research International, 25(23), 22541-22551. https://doi.org/10.1007/s11356-018-2362-y

Wan Ismail, W.H., Jaafar, A.A. and Che Mohd Ramli,
N.K. (2013). Pepper. Jengka, Pahang: Unit Penerbitan Universiti Teknologi MARA.

Wan Salleh, W.M., Hashim, N.A., Ahmad, F. and Yen, K.H. (2014). Anticholinesterase and Antityrosinase Activities of Ten Piper Species from Malaysia. Advanced Pharmaceutical Bulletin, 4(2), 527-531.

Tu, Y., Zhong, Y., Du, H., Luo, W., Wen, Y., Li, Q., Zhu, C. and Li, Y. (2015). Anticholinesterases and Antioxidant Alkamides from Piper nigrum Fruits. National Product Research, 30(17), 1945-1949. https://doi.org/10.1080/14786419.2015.1089243

Zarubová, L., Kourimska, L., Zouhar, M., Novy, P., Douda, O. and Skuhrovec, J. (2014). Botanical Pesticides and their Human Health Safety on the example of Citrus sinensis Essential Oil and Oulema melanopus under Laboratory Conditions. Acta Agriculture Scandinavica, Section B - Soil and Plant Science, 65(1), 89-93. https:// doi.org/10.1080/09064710.2014.959556 